\title{
PENGARUH ASIMETRI INFORMASI DAN UKURAN PERUSAHAAN TERHADAP MANAJEMEN LABA
}

(Studi Empiris Perusahaan ConsumersGoods Industry Periode 2011 - 2015)

\section{AMALIA INDAH FITRIANA DAN HENDRA GALUH FEBRIANTO}

\author{
Fakultas Ekonomi dan Bisnis \\ Universitas Muhammadiyah Tangerang \\ e-mail : (amalia@umt.ac.id)
}

\begin{abstract}
This study aims to analyze the influence of information asymmetry and firm size on earnings management.

In this study the object of research is the Indonesia Stock Exchange. Indonesia Stock Exchange (IDX) or can also called Indonesia Stock Exchange (IDX). Form data in this research is quantitative data. The data used in this research is the company's financial report along with independent auditor's report on the consumer goods industry in IDX period 2011-2015. The sample is determined by purposive sampling. Data analysis methods used consist of descriptive statistical analysis, classical assumption test analysis, multiple linear regression analysis, coefficient of determination and correlation coefficient, and hypothesis test.

Based on the results of research show the value of correlation coefficient $(R)$ of 0.230 . From the calculation results can be concluded the relationship between variables Asymmetry Information (X1), and Company Size (X2) to variable Management Profit (Y) is weak and positive. While the value of coefficient of determination (R2) seen from Adjusted R Square shows the value of 0.039 or $3.9 \%$. Hypothesis test results show the sign value of 0,048 that information asymmetry significant effect on earnings management. The firm size variable shows a sign value of 0.98 that firm size has no significant effect on earnings management. While testing simultaneously shows sign value of 0.028 that information asymmetry and firm size together have significant effect to earnings management.
\end{abstract}

Keywords: information asymmetry, firm size, earnings management

\begin{abstract}
ABSTRAKSI
Penelitian ini bertujuan menganalisis pengaruh asimetri informasi dan ukuran perusahaan terhadap manajemen laba.

Dalam penelitian ini objek penelitian adalah Bursa Efek Indonesia. Bursa Efek Indonesia (BEI) atau dapat juga disebut Indonesia Stock Exchange (IDX). Bentuk data dalam penelitian ini adalah data kuantitatif. Data yang digunakan dalam penelitian ini merupakan laporan keuangan perusahaan beserta laporan auditor independen pada perusahaanconsumer goods industry di BEI periode 20112015. Sampel penelitian ditentukan secara purposive sampling. Metode analisis data yang digunakan terdiri dari antara lain : analisis statistik deskriptif, analisis uji asumsi klasik, analisis regresi linier berganda, analisis koefisien determinasi dan koefisien korelasi, dan uji hipotesis.

Berdasarkan hasil penelitian menunjukkan nilai koefisien korelasi (R) sebesar 0,230. Dari hasil perhitungan tersebut dapat disimpulkan hubungan antara variabel Asimetri Informasi $\left(\mathrm{X}_{1}\right)$, dan Ukuran Perusahaan $\left(\mathrm{X}_{2}\right)$ terhadap variabel Manajemen Laba $(\mathrm{Y})$ adalah lemah dan positif. Sedangkan nilai koefisien determinasi $\left(\mathrm{R}^{2}\right)$ dilihat dari Adjusted $R$ Square menunjukkan nilai sebesar 0,039 atau 3,9\%. Hasil uji hipotesis menunjukkan nilai sign sebesar 0,048 bahwa asimetri informasi berpengaruh
\end{abstract}


signifikan terhadap manajemen laba. Variabel ukuran perusahaan menunjukkan nilai sign sebesar 0,98 bahwa ukuran perusahaan tidak berpengaruh signifikan terhadap manajemen laba. Sedangkan pengujian secara simultan menunjukkan nilai sign 0,028 bahwa asimetri informasi dan ukuran perusahaan bersama-sama berpengaruh signifikan terhadap manajemen laba.

Kata kunci : asimetri informasi, ukuran perusahaan, manajemen laba

\section{PENDAHULUAN}

Manajemen laba merupakan salah satu skebijakan manajemen dalam memanipulasi laporan keuangan dengan disengaja, menurut standar akuntansi keuangan untuk mengarahkan pelaporan laba pada tingkat tertentu. Manajemen laba dalam proses pelaporan keuangan eksternal yang diakibatkan oleh asimetri informasi ini bertujuan menguntungkan dan salah satu faktor mengurangi kualitas laporan keuangan, sehingga hal ini dapat mengganggu pemakai dengan melihat angka hasil rekayasa tersebut. Informasi merupakan hal yang terpenting dalam dunia bisnis. Informasi tersebut yang relevan dan lengkap dibutuhkan untuk kelancaran bisnis dan secara tidak langsung berkaitan efisiensi dan efektivitas, dan ekononomis. Namun informasi dapat menimbulkan cost tersendiri, sehingga tidak heran akan menimbulkan menyembunyikan informasi dari pihak lain yang disebut dengan asimetri informasi. Asimetri informasi terjadi pihak manajemen yang memiliki informasi lebih dibanding pihak lain. Implikasi asimatri informasi adalah Agency Theory antara manajer dan pemilik

Asimetri informasi, Manajemen laba, dan ukuran perusahaan merupakan isu yang paling sering diteliti bidang akuntansi dan manajemen keuangan, namun masih terdapat research gap di dalamnya. Penelitian terdahulu variabel asimetri informasi terhadap manajemen laba dengan hasil berbeda beda. Hasil positif signifikan hasil penelitian Veronica dan Bachtiar (2004), Halim (2005), Rahmawati, dkk (2006), Setyaningrum 2011), dan Putra (2014). Hasil tidak berpengaruh penelitian Kusumawati (2013). Penelitian mengenai ukuran perusahaan terhadap manajemen laba dengan hasil negatif signifikan dari penelitian Setyaningrum (2011). Penelitian lain hasil positif signifikasn yang dilakukan oleh Halim (2005), Budiasih (2007), Arfan (2010), dan Putra (2014). Penelitian mengenai kualitas laporan keuangan terhadap asimetri informasi dengan hasil negatif signifikan dari penelitian Indriani dan Khoiriyah (2010) dan Fanani (2009). Penelitian lain hasil negatif tidak signifikan yang dilakukan oleh Kusuma (2014) dan Santoso (2012).

Dari hasil teori dan hasil penelitian sebelumnya yang masih berbeda-beda (research gap), maka penelitian ini mencoba mengkaji apakah asimetri informasi dan ukuran perusahaan berpengaruh terhadap manajemen laba dalam pelaporan akuntansi pada perusahaan Consumers Goods Industry.

\section{KAJIAN LITERATUR DAN PENGEMBANGAN HIPOTESIS Teori Keagenan(Agency Theory)}

Teori keagenan dalam penelitian ini digunakan untuk menjelaskan hubungan antara agen (manajemen) dan pricipal (pemilik). Di dalam hubungan tersebut terdapat suatu kontrak dimana si agen menutup kontrak untuk melakukan tugas dan kewajiban tertentu bagi principal, si principal menutup kontrak untuk memberi imbalan kepada agen. Teori keagenan memiliki asumsi bahwa setiap individu termotivasi oleh kepentingan dirinya sendiri sehingga menimbulkan konflik kepentingan (conflict interest) antara agen dan principal.

Manajemen laba khususnya tindakan perataan laba adalah tindakan manajemen yang dimotivasi oleh aspek-aspek perilaku di dalam perusahaan dan lingkungannya. Adanya asimetri informasi dalam suatu perusahaan dapat menimbulkan manajemen laba. ukuran perusahaan yang diproksi menggunakan total aset perusahaan dalam penelitian ini yang lebih besar memiliki dorongan yang lebih kecil pula untuk melakukan perataan laba dibandingkan dengan perusahaan-perusahaan yang lebih besar karena perusahaan-perusahaan yang lebih besar menjadi subyek pemeriksaan (pengawasan yang lebih ketat dari pemerintah dan masyarakat umum/general public). Sehingga 
dengan adanya mediasi manajemen laba di perusahaan akan mengakibatkan menurunnya tingkat kualitas laporan keuangan dalam pasar modal.

\section{Teori Sinyal (Signalling Theory)}

Teori sinyal tidak dapat dipisahkan dengan keberadaan asimetri informasi karena dalam kerangkanya yang terjadi antara prinsipal dan agen mengungkapkan sinyal dari perusahaan, merupakan hal penting yang diperhatikan agar perusahaan berhasil memperoleh dan/atau mempertahankan sumber daya ekonomi.

Teori sinyal digunakan untuk menjelaskan mengapa perusahaan mempunyai dorongan untuk memberikan informasi laporan keuangan kepada pihak eksternal. Dorongan tersebut perusahaan beralasan karena terdapat asimetri informasi antara perusahaan dan pihak luar karena perusahaan mengetahui lebih banyak mengenai kondisi perusahaan dan peluang yang akan datang daripada pihak eksternal (investor, kreditor). Kurangnya informasi bagi pihak eksternal mengenai keadaan perusahaan menyebabkan mereka melindungi diri mereka dengan memberikan harga yang rendah untuk perusahaan. Perusahaan dapat meningkatkan nilai perusahaan dengan mengurangi informasi asimetri. Salah satu cara untuk mengurangi informasi asimetri adalah dengan memberikan sinyal pada pihak luar, salah satunya berupa informasi keuangan yang dapat dipercaya dan akan mengurangi ketidakpastian mengenai peluang yang akan datang.

\section{Asimetri Informasi}

Dasar dari teori asimetri informasi berasal dari pengusaha dalam pasar tenaga kerja yang sering mempunyai informasi lebih banyak tentang status sekarang dan di masa mendatang perusahaannya, dan dapat menggunakan kelebihan ini sebagai basis negosiasi. Hal ini dapat dilihat sebagai suatu ketidaksempurnaan dalam bekerjanya mekanisme pasar dan dapat menyebabkan efesiensi ekonomik. Kondisi inilah yang membuat manajemen memanfaatkan ketidakselarasan informasi untuk mencari keuntungan pihak manajemen sendiri serta sekaligus dapat menimbulkan kerugian pihak luar perusahaan seperti membiaskan informasi yang terkait dengan investor.

Asimetri informasi menurut bahasa bisnis merupakan suatu keadaan yang terjadi ketika antara kedua pihak yang bertransaksi tidak mempunyai informasi relevan yang sama. Sedangkan menurut Jansen dan Meckling (1976) dalam Rahmawati, dkk (2006) definisi asimetri informasi adalah jika antara kedua kelompok (agen dan prinsipal) tersebut adalah orang-orang yang berupaya memaksimalkan utilitasnya, maka terdapat alasan yang kuat untuk meyakini bahwa agen tidak akan selalu bertindak yang terbaik untuk kepentingan prinsipal.

\section{Ukuran Perusahaan}

Ukuran perusahaan merupakan suatu skala dimana dapat diklasifikasikan skala besar kecilnya suatu perusahaan dengan berbagai cara, yaitu total aktiva, penjualan, atau modal dari perusahaan tersebut. Ketiga variabel ini digunakan untuk menentukan ukuran perusahaan karena dapat mewakili seberapa besar perusahaan tersebut. Semakin besar aktiva maka semakin banyak modal yang ditanam, semakin banyak penjualan maka semakin banyak pula perputaran uang dan semakin besar pula ia dikenal di dalam masyarakat. Besar kecilnya perusahaan dapat diukur dengan total aktiva/besar harta perusahaan dengan menggunakan perhitungan logaritma natural total aktiva. Total aktiva digunakan sebagai proxy ukuran perusahaan dengan mempertimbangkan bahwa nilai aktiva relatif lebih stabil dibandingkan dengan nilai market capitalized dan penjualan.

\section{Manajemen Laba}

Laporan keuangan yang paling sering dimanipulasi oleh perusahaan adalah laporan rugi laba. Suatu proses manipulasi yang disengaja, menurut standar akuntansi keuangan untuk mengarahkan pelaporan laba pada tingkat tertentu disebut manajemen laba.

Gunny (2005) mengelompokkan manajemen laba dalam tiga kategori yaitu akuntansi yang curang, manajemen laba akrual, dan manajemen laba riil (real earnings management). Akuntansi yang curang meliputi pemilihan akuntansi yang melanggar prinsip-prinsip akuntansi yang berlaku umum. Manajemen laba akrual menurut Dechow dan Skinner (2000) meliputi pilihan akuntansi yang diperbolehkan dalam prinsip akuntansi yang berlaku umum yang mencoba untuk menutupi atau mengaburkan kinerja perusahaan yang sebenarnya. Manajemen laba riil terjadi ketika manajer melakukan tindakan yang menyimpang dari praktik operasi normal perusahaan untuk meningkatkan laba yang dilaporkan.

Manajemen laba menurut Scott (2000) membagi cara pemahaman atas manajemen laba menjadi 2 (dua), yaitu :Pertama, melihatnya sebagai perilaku oportunistik manajer untuk memaksimumkan 
utilitasnya dalam menghadapi kontrak kompensasi, kontrak utang dan political costs (oportunistic Earnings Management). Kedua, dengan memandang manajemen laba dari perspektif efficient contracting (Efficient Earnings Management), dimana manajemen laba memberi manajer suatu fleksibilitas untuk melindungi diri mereka dan perusahaan dalam mengantisipasi kejadian-kejadian yang tak terduga untuk keuntungan pihak-pihak yang terlibat dalam kontrak.

\section{Hipotesis Penelitian}

Manajemen laba khususnya tindakan perataan laba adalah tindakan manajemen yang dimotivasi oleh aspek-aspek perilaku di dalam perusahaan dan lingkungannya. Adanya asimetri informasi dalam suatu perusahaan dapat menimbulkan manajemen laba. ukuran perusahaan yang diproksi menggunakan total aset perusahaan-perusahaan dalam penelitian ini yang lebih besar memiliki dorongan yang lebih kecil pula untuk melakukan perataan laba dibandingkan dengan perusahaan-perusahaan yang lebih besar karena perusahaan-perusahaan yang lebih besar menjadi subyek pemeriksaan (pengawasan yang lebih ketat dari pemerintah dan masyarakat umum/general public). Sehingga dengan adanya mediasi manajemen laba di perusahaan akan mengakibatkan menurunnya tingkat kualitas laporan keuangan dalam pasar modal.

Berdasar kepada landasan teori, beberapa penelitian terdahulu yang telah dilakukan oleh beberapa peneliti, dan rumusan masalah diatas maka hipotesis yang diajukan sebagai berikut :

H1 : asimetri informasi berpengaruh positif dan signifikan terhadap praktik manajemen laba.

$\mathrm{H} 2$ : ukuran perusahaan berpengaruh positif dan signifikan terhadap praktik manajemen laba.

$\mathrm{H} 3$ : ukuran perusahaan dan asimetri informasi bersama-sama berpengaruh positif dan signifikan terhadap praktik manajemen laba.

\section{METODE PENELITIAN}

\section{Populasi, Sampel, Teknik Pengumpulan Data}

Dalam penelitian ini objek penelitian adalah Bursa Efek Indonesia. Bursa Efek Indonesia (BEI) atau dapat juga disebut Indonesia Stock Exchange(IDX). Populasi dalam penelitian ini yaitu perusahaan consumer goods industry di BEI periode 2011-2015 sebanyak 200 perusahaan. Pemilihan perusahaan secara purposive sampling diantaranya publish Laporan Tahunan secara konsisten selama periode penelitian, Perusahaan yang Audited, menggunakan Rupiah dalam pelaporannya. Sehingga sampel yang digunakan dalam penelitian menjadi sebanyak 110 perusahaan.

Bentuk data dalam penelitian ini adalah data kuantitatif. Metode dalam pengumpulan data dalam penelitian ini adalah dengan studi literatur melalui pencarian data sekunder, konsep atau teori dari buku, tesis, skripsi, jurnal nasional, website, regulasi atau peraturan terkait.

Data yang digunakan dalam penelitian ini merupakan laporan keuangan perusahaan beserta laporan auditor independen pada perusahaanconsumer goods industry di BEI periode 2011-2015. Sampel penelitian ditentukan secara purposive sampling. Metode analisis data yang digunakan terdiri dari antara lain : analisis statistik deskriptif, analisis uji asumsi klasik, analisis regresi linier berganda, analisis koefisien determinasi dan koefisien korelasi, dan uji hipotesis.

\section{Definisi Operasional dan Pengukuran Variabel Manajemen Laba (Earning Management)}

Manajemen laba khususnya tindakan perataan laba adalah tindakan manajemen yang dimotivasi oleh aspek-aspek perilaku di dalam perusahaan dan lingkungannya.Manajemen laba dalam penelitian ini diukur dengan perataan laba. Perataan laba diukur model Eckel (1981). Eckel menggunakan nilai absolut Coefficient Variation (CV) variabel penghasilan bersih/laba dan variabel penjualan bersih. Jika perusahaan melakukan perataan laba diberi nilai 1, sedangkan sebaliknya diberi nilai 0.Perataan 
laba meliputi penggunaan teknik-teknik tertentu untuk memperkecil atau memperbesar jumlah laba suatu periode sama dengan jumlah periode sebelumnya.

Indeks Eckel dihitung dengan rumus :

$$
\text { Indeks perataan laba }=\frac{\mathrm{CV} \Delta \mathrm{I}}{\mathrm{CV} \Delta \mathrm{S}}
$$

Keterangan :

$\Delta \mathrm{I}=$ perubahan laba dalam satu periode

$\Delta \mathrm{S}=$ perubahan penjualan dalam satu periode

$\mathrm{CV}=$ koefisien variasi dari variabel yaitu standar deviasi dibagi dengan nilai yang diharapkan

\section{Asimetri Informasi}

Asimetri informasi adalah suatu keadaan dimana manajer memiliki akses informasi atas prospek perusahaan yang tidak dimiliki oleh pihak luar perusahaan. Rumus Asimetri informasi dalam penelitian dengan rumus sebagai berikut :

$$
\text { SPREADi,t }=(\text { aski,t }- \text { bidi,t }) /\{(\text { aski,t }+ \text { bidi,t }) / 2\} \times 100
$$

Keterangan :

Aski,t : harga ask tertinggi saham perusahaan i yang terjadi pada tahun $\mathrm{t}$

Bidi,t : harga bid terendah saham perusahaan i yang terjadi pada tahun $\mathrm{t}$

\section{Ukuran perusahaan}

Ukuran perusahaan menggambarkan besar kecilnya perusahaan yang dapat dinyatakan dengan total aktiva. Semakin besar total aktiva maka semakin besar pula ukuran suatu perusahaan. Ukuran perusahaan dalam penelitian diukur yaitu :

$$
\text { Ukuran Perusahaan }=\Sigma \log \text { TA }
$$

\section{Metode Analisis Data}

Sebelum diolah dalam suatu persamaan matematis, terlebih dahulu dilakukan uji asumsi klasik pada data yang akan dianalisis, yaitu uji normalitas dengan kolmogorov-Smirnov, uji heterosekedasitas dengan uji Glejser, dan uji autokorelasi dengan Durbin Watson (D-W). Selanjutnya data akan dianalisis faktor, dan menguji pengaruh asimetri informasi dan ukuran perusahaan terhadap informasi asimetri dengan regresi sederhana, dengan persamaan regresi yang digunakan sebagai berikut :

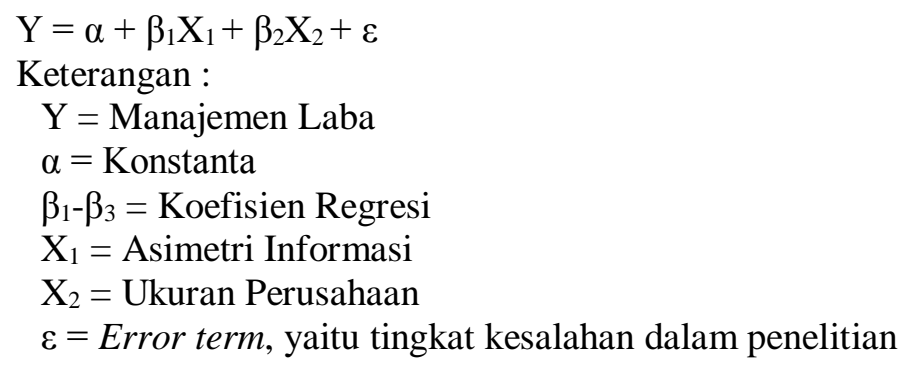

\section{HASIL PENELITIAN}

\section{Sampel Penelitian}

Kriteria pemilihan sampel sebagai berikut :

1. Perusahaan consumers goods industry yang konsisten terdaftar di BEI selama periode 2011 2015.

2. Perusahaan menerbitkan laporan keuangan tahunan yang dinyatakan dalam Rupiah (Rp) selama periode $2011-2015$.

3. Laporan keuangan perusahaan diaudit oleh Kantor Akuntan Publik (KAP).

4. Data yang tersedia lengkap selama periode $2011-2015$. 
Berikut ini hasil seleksi sampel pada tahun yang bersangkutan :

Tabel

Hasil Seleksi Sampel Penelitian

\begin{tabular}{|l|l|r|}
\hline No. & \multicolumn{1}{|c|}{ Kriteria } & Jumlah Perusahaan \\
\hline 1. & $\begin{array}{l}\text { Perusahaan consumers goods industry yang terdaftar di } \\
\text { BEI pada tahun 2011 - 2015 secara keseluruhan }\end{array}$ & 200 \\
\hline 2. & $\begin{array}{l}\text { Perusahaan consumers goods industry yang tidak } \\
\text { konsisten terdaftar di BEI dan tidak lengkap sesuai } \\
\text { variabel penelitian pada tahun 2011 - 2015 }\end{array}$ & (65) \\
\hline & Jumlah Sampel periode 2011 -2015 & 135 \\
\hline
\end{tabular}

Sumber : Data yang diolah hasil pemilihan sampel

\section{Analisis Statistik Deskriptif}

Tabel

Analisis Deskriptif

\begin{tabular}{|l|c|r|r|r|r|}
\hline & $\mathrm{N}$ & Minimum & Maximum & \multicolumn{1}{c|}{ Mean } & \multicolumn{1}{c|}{ Std. Deviation } \\
\hline ASIMETRI INFORMASI & 135 & 0,00 & 67,00 & 17,3481 & 13,16277 \\
SIZE & 135 & 11,00 & 13,96 & 12,4077 & 0,74948 \\
MNJ LABA & 135 & 0,00 & 1,00 & 0,1852 & 0,38989 \\
Valid N (listwise) & 135 & & & & \\
\hline
\end{tabular}

Pada tabel diatas diperoleh rata-rata (mean), tingkat penyimpangan penyebaran data (standar deviasi) serta jumlah total populasi untuk setiap variabel penelitian. Nilai rata-rata (mean) diperoleh dari jumlah data penelitian keseluruhan dibagi dengan jumlah sampel. Sehingga diperoleh nilai minimum Ukuran Perusahaan dengan log total asset sebesar 11,00 dan nilai maksimumnya 67,00 dengan nilai rata-rata pada variabel adalah 17,3481 dan standar deviasi sebesar 0,74948. Sedangkan untuk variabel Manajemen Laba nilai minimum 0,00 dan nilai maksimum 1,00 dan nilai standar deviasi sebesar 0,38989

\section{Analisis Uji Asumsi Klasik}

Hasil penelitian ini dari pengujian Regresi Linier Berganda akan dapat digunakan sebagai alat prediksi yang tepat apabila memenuhi uji asumsi klasiksebagai berikut:

1. Uji Normalitas

Uji normalitas data bertujuan untuk menguji apakah dalam model regresi variable pengganggu atau residual memiliki distribusi normal. Normalitas distribusi data penelitian ini dapat dilihat dari normal probability plot, jika data menyebar disekitar garis diagonal dan mengikuti arah garis diagonal, maka model regresi dikatakan memenuhi asumsi normalitas dan sebaliknya jika tersebar acak dan tidak berada disekitar garis diagonal maka asumsi normalitas tidak terpenuhi (Ghozali, 2011: 160).

2. Uji Multikolenieritas

\section{Tabel}

Hasil Uji Multikolinieritas Dengan Tolerance Value dan VIF

\begin{tabular}{|c|c|c|c|}
\hline \multirow{2}{*}{ Model } & \multicolumn{2}{|c|}{ Collinearity Statistics } & \multirow{2}{*}{ Kesimpulan } \\
\cline { 2 - 3 } (Constant) & Tolerance & VIF & \\
\hline Asimetri Informasi & & & \\
\hline Ukuran Perusahaan & 0.995 & 1.005 & Tidak ada multikolinieritas \\
\hline
\end{tabular}

Sumber : Data Diolah

Hasil pengujian menunjukkan tidak ada nilai tolerance yang kurang dari 10\%. Demikian juga hasil VIF yang menunjukkan tidak ada satupun variabel independent yang memiliki nilai VIF 
lebih dari 5. jadi dapat disimpulkan bahwa tidak terdapat gejala multikolinearitas antara variabel independent dan model regresi.

3. Uji Heterokedastisitas

Hasil Uji Glejser menunjukkan bahwa pada tahap growth dan mature tidak ada variabel yang signifikasi 0,05 . Hal ini tidak terjadi heterokedastisitas. Sebaliknya pada tahap start-up dan decline terdapat heterokedastisitas dikarenakan ada variabel yang signifikan 0,05.

4. Uji Autokorelasi

adanya hubungan antara kesalahan-kesalahan yang muncul pada data runtun waktu (time series). Salah satu cara untuk mendeteksi ada tidaknya autokorelasi adalah dengan uji Durbin-Watson (DW test).Berdasarkan hasil pengujian menunjukkan bahwa pada tahap start-up dan growth terbebas dari autokorelasi dan pada tahap mature dan decline tidak dapat diambil kesimpulan apakah terjadi autokorelasi atau tidak disebabkan nilai d terletak antara $\mathrm{dL}$ dan dU atau antara (4dU) dan (4-dL).

Analisis Regresi Linier Berganda

Tabel

Hasil Perhitungan Regresi Berganda

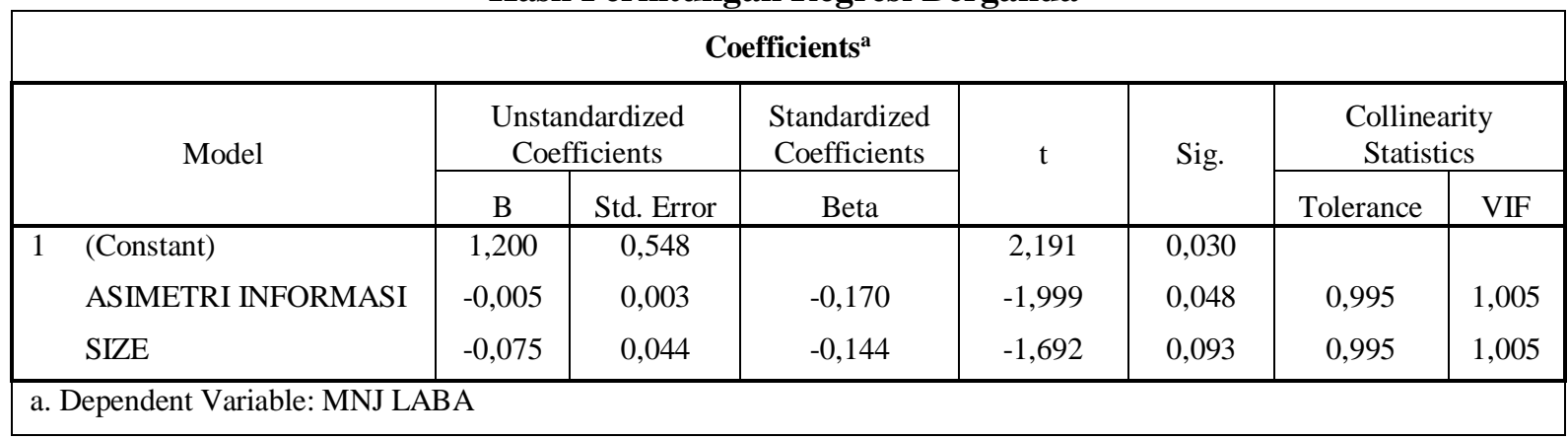

Sumber : Data Diolah

Berdasarkan hasil analisis regresi pada tabel diatas, dapat dibuat persamaan regresi untuk model penelitian sebagai berikut :

$\mathrm{Y}=1,200-0,005 \mathrm{X}_{1}-0,075 \mathrm{X}_{2}+\varepsilon$

\section{Analisis Koefisien Korelasi( $(\mathbf{R})$ Dan Koefisien Determinasi $\left(\mathbf{R}^{2}\right)$}

Uji Koefisien Korelasi dilakukan dengan cara mengkorelasikan setiap item-item pertanyaan dengan total nilai setiap variabel, korelasi setiap item pertanyaan dengan nilai total setiap variabel. Koefisien Korelasi (R) untuk menunjukkan seberapa besar kuat atau lemah hubungan variabel independen menjelaskan variabel dependennya. Sedangkan koefisien determinasi digunakan untuk menguji seberapa besar pengaruh variabel independen terhadap variabel dependen. Penggunaan nilai Adjusted $\mathrm{R}^{2}$ pada saat mengevaluasi model regresi lebih disarankan karena nilai Adjusted $\mathrm{R}^{2}$ dapat naik atau turun apabila satu variabel independen ditambahkan ke dalam model (Ghozali, 2011: 97).

\section{Tabel}

\section{Pengujian Durbin Watson}

\begin{tabular}{|c|r|r|r|r|r|}
\hline \multicolumn{7}{|c|}{ Model Summary $^{\mathbf{b}}$} \\
\hline Model & $\mathrm{R}$ & R Square & $\begin{array}{c}\text { Adjusted R } \\
\text { Square }\end{array}$ & $\begin{array}{c}\text { Std. Error of the } \\
\text { Estimate }\end{array}$ & Durbin-Watson \\
\hline 1 & $0.230^{\mathrm{a}}$ & 0,053 & 0,039 & 0,38230 & 1,904 \\
\hline
\end{tabular}

Sumber : Data diolah 
Dari diatas diperoleh nilai koefisien korelasi (R) sebesar 0,230. Dari hasil perhitungan tersebut dapat disimpulkan hubungan antara variabel Asimetri Informasi $\left(\mathrm{X}_{1}\right)$, dan Ukuran Perusahaan $\left(\mathrm{X}_{2}\right)$ terhadap variabel Manajemen Laba (Y) adalah lemah dan positif, dimana nilai $\mathrm{R}$ berada pada rentang 0,400,60 . Sedangkan nilai koefisien determinasi $\left(\mathrm{R}^{2}\right)$ dilihat dari Adjusted $R$ Square menunjukkan nilai sebesar 0,039 yang berarti varibialitas variabel - variabel dependen yang dapat dijelaskan oleh independen sebesar 3,9\%. Hal ini berarti 3,9\% manajemen laba dipengaruhi oleh asimetri informasi dan ukuran perusahaan. Sisanya yaitu $96,1 \%$ dipengaruhi oleh variabel lain yang tidak diteliti didalam penelitian ini.

\section{Uji Hipotesis}

\begin{tabular}{|l|l|l|l|l|}
\hline & \multicolumn{1}{|c|}{ Uji t } & \multicolumn{1}{c|}{ Sig } & \multicolumn{1}{c|}{ A } & \multicolumn{1}{c|}{ Hasil } \\
\hline Asimetri Informasi & $-1,999$ & 0,048 & 0,05 & Berpengaruh \\
\hline Size & $-1,692$ & 0,093 & 0,05 & Tidak Berpengaruh \\
\hline
\end{tabular}

Sumber : Data diolah

Berdasarkan pengujian hipotesis yang telah dilakukan, maka didapat hasil seperti pada table diatas. Variabel asimetri informasi berpengaruh terhadap manajemen laba karena nilai signifikan dibawah 0,05 atau $5 \%$. Sementara variabel ukuran perusahaan tidak berpengaruh terhadap manajemen laba karena nilai signifikan diatas 0,05 atau $5 \%$.

\section{Pembahasan}

\section{Pengaruh Asimetri Informasi terhadap Manajemen Laba}

Dari pengujian secara parsial variabel Asimetri Informasi $\left(\mathrm{X}_{1}\right)$ terhadap Manajemen Laba (Y), diperoleh hasil pengujian individual menunjukkan nilai $t$ sebesar -1,999 dan nilai sign sebesar 0,048, hal ini menunjukkan nilai sign>0,05. Dengan demikian dapat disimpulkan bahwa $\mathrm{H} 1$ menyatakan yang berarti asimetri informasi berpengaruh terhadap manajemen laba, diterima.

Hasil temuan penelitian menunjukkan bahwa asimetri informasi berpengaruh terhadap manajemen laba. Relative bid-ask spread digunakan untuk mengukur asimetri informasi dalam statistik deskriptif nilai mean tingkat asimetri informasi nilai bid-ask spread dibawah 20 kriteria tidak terjadi asimetri informasi. Sedangkan dilihat dari statistik deskriptif variabel manajemen menunjukkan dari 135 perusahaan bahwa nilai 1 yang menunjukan melakukan manajemen laba periode penelitian 2011 - 2015 sebanyak 25 perusahaan dan sisanya tidak melakukan manajemen laba.

Hasil temuan tersebut artinya apabila semakin kecil nilai bid-ask spread pada asimetri informasi semakin besar indikasi manajemen untuk melakukan praktik manajemen laba. Hal ini karena perusahaan sampel di tahun 2016 banyak melakukan manajemen laba yang kurang menerapkan kode etik dan budaya perusahaan yang tinggi. Kode etik ini merupakan panduan umum bagi komisaris, direksi, dan karyawan perusahaan dan entitas anak dalam menjalankan etika berbisnis dan pekerjaan masing-masing, sehingga dapat membentuk budaya perusahaan yang sesuai dengan nilai-nilai dasar perusahaan. Disamping itu dikarenakan faktor suasana pemilu pilpres 2015 Oleh karena itu sebagai pengelola, manajer berkewajiban memberikan sinyal mengenai kondisi perusahaan kepada pemilik. Sinyal yang diberikan dapat dilakukan melalui pengungkapan informasi akuntansi seperti laporan keuangan. Sehingga informasi yang disampaikan diterima sesuai dengan kondisi perusahaan sebenarnya atau transparansi. Oleh karena itu, asimetri antara manajemen (agent) dengan pemilik (principal) dalam perusahaan sampel tidak memberikan kesempatan kepada manajer untuk bertindak oportunis, yaitu memperoleh keuntungan pribadi (manajemen laba).

\section{Pengaruh Ukuran Perusahaan terhadap Manajemen Laba}

Dari hasil pengujian secara parsial variabel Ukuran Perusahaan $\left(\mathrm{X}_{2}\right)$ terhadap Manajemen Laba (Y), diperoleh hasil pengujian ukuran perusahaan menunjukkan nilai $t$ sebesar 0,947 dan nilai sign sebesar 0,176 yang berarti nilai sign> 0,05. Dengan demikian H2 ditolak dan mengambil keputusan bahwa ukuran perusahaan tidak berpengaruh terhadap praktik manajemen laba, ditolak. 
Hasil pengujian hipotesis menunjukkan bahwa ukuran perusahaan tidak berpengaruh terhadap manajemen laba. Total Log Asset digunakan untuk mengukur ukuran perusahaan dilihat dari hasil statistik deskriptif rata-rata ukuran perusahaan bisa dikatakan tingkat ukuran berskala sedang dan ukuran perusahaan dari periode penelitian 2011 - 2015 mengalami kenaikan. Sedangkan dilihat dari statistik deskriptif variabel manajemen menunjukkan dari 120 perusahaan bahwa nilai 1 yang menunjukan melakukan manajemen laba periode penelitian 2011 - 2015 sebanyak 25 perusahaan dan sisanya tidak melakukan manajemen laba. Hal tersebut menandakan bahwa pada perioda tahun 2011-2015 perusahaan consumers goods industry di Indonesia rata-rata tidak melakukan praktik manajemen laba dengan pola meratakan labanya.

Jadi hal ini dapat menunjukkan bahwa perusahaan sampel semakin besar ukuran perusahaan maka semakin kecil peluang yang dimiliki manajer untuk melakukan praktik manajemen laba. Ukuran perusahaan yang besar menunjukkan bahwa perusahaan telah mencapai tahap kedewasaan (maturity) dimana dalam tahap ini arus kas perusahaan sudah positif dan dianggap memiliki prospek yang baik dalam jangka waktu yang relatif lama dan mencerminkan bahwa perusahaan relatif lebih stabil. Oleh karena itu sebagai pengelola, manajer berkewajiban memberikan sinyal mengenai kondisi perusahaan kepada investor. Sinyal yang diberikan dapat dilakukan melalui pengungkapan informasi akuntansi seperti laporan keuangan. Ukuran perusahaan dapat menunjukkan oportunity bagi para investor untuk menginvestasikan dan memberikan kepercayaan mengelola investasi kepada stakeholder, yaitu memperoleh keuntungan mereka.

\section{Asimetri Informasi dan Ukuran Perusahaan bersama-sama berpengaruh terhadap Manajemen Laba}

Dari hasil analisis statistik uji $\mathrm{F}$ dapat diperoleh nialai bahwa variabel asimetri informasi dan ukuran perusahaan mempunyai nilai signifikan sebesar 0,028 yang berada dibawah nilai signifikan 0,05.nilai koefisien determinasi $\left(\mathrm{R}^{2}\right)$ menunjukkan nilai sebesar 0,039 atau 3,9\%, sehingga mempunyai arah positif dan berkorelasi lemah. Dengan demikian dapat disimpulkan bahwa Asimetri Informasi dan Ukuran Perusahaan berpengaruh signifikan terhadap Manajemen Laba, maka H3 diterima.

\section{KESIMPULAN \\ Simpulan}

Berdasarkan hasil pengujian statistik dengan menggunakan regresi linear berganda, maka kesimpulan yang diperoleh yaitu:

1. Asimetri informasi berpengaruh signifikan terhadap manajemen laba.

2. Ukuran perusahaan berpengaruh signifikan terhadap manajemen laba.

3. Asimetri informasi dan ukuran bersama-sama berpengaruh signifikan terhadap manajemen laba.

4. Nilai koefisien determinasi $\left(\mathrm{R}^{2}\right)$ menunjukkan nilai sebesar 0,039 yang berarti varibialitas variabel - variabel dependen yang dapat dijelaskan oleh independen sebesar 3,9\%. Hal ini berarti 3,9\% manajemen laba dipengaruhi oleh asimetri informasi dan ukuran perusahaan. Sisanya yaitu 96,1\% dipengaruhi oleh variabel lain yang tidak diteliti didalam penelitian ini.

\section{Keterbatasan Penelitian}

Penelitian ini mempunyai keterbatasan - keterbatasan antara lain sebagai berikut :

1. Penelitian ini hanya fokus dengan tiga variable, yaitu asimetri informasi dan ukuran perusahaan sebagai variable independen dan manajemen laba sebagai variable dependen

2. Penelitian ini menggunakan perusahaan Consumers Goods Industry dengan periode penelitian selama 5 tahun yaitu $2011-2015$

\section{Saran}

Berdasarkan kesimpulan dan keterbatasan diatas, maka saran yang dapat diberikan penulis untuk penelitian selanjutnya adalah sebagai berikut: 
1. Penelitian selanjutnya dapat mengembangkan penelitian ini dengan menambahkan variabel lain yang tidak dimasukkan dalam penelitian ini.

2. Penelitian selanjutnya dapat memilih periode tahun terbaru.

3. Penelitian berikutnya disarankan untuk menggunakan sampel yang lebih besar dengan objek serta periode penelitian yang lebih luas supaya penelitian dapat digeneralisasi lebih luas.

4. untuk para investor adalah hasil penelitian ini diharapkan investor juga lebih selektif dan berhati - hati dalam membuat keputusan untuk berinvestasi di suatu perusahaan. Dan diharapkan emiten meningkatkan kinerjanya dengan tidak melakukan asimetri informasi dan manajemen laba demi keuntungan sendiri agar meningkatnya kualitas laporan keuangan dengan kondisi perusahaan yang sesungguhnya.

\section{DAFTAR PUSTAKA}

Arfan. 2010. Pengaruh Firm Size, Winner/Loser Stock, Dan Debt To Equity Ratio Terhadap Perataan Laba (Studi Pada Perusahaan Manufaktur Yang Terdaftar Di Bursa Efek Indonesia). Jurnal Telaah \& Riset Akuntansi. Vol. 3. No. 1 Hal. 52-65. Fakultas Ekonomi Universitas Syiah Kuala.

Belkaouli, Ahmed. 1999. Accounting Theory. Illinois, USA : University of Illinois at Chicago.

Dechow, Patricia M., dan Skinner, Douglas J. 2000. Earnings Management: Reconciling the Views of Accounting Academics, Practitioners, and Regulators. Accounting Horizons. 14, p: 235-250.

Fanani, Z., 2009, Kualitas Pelaporan Keuangan: Berbagai Faktor Penentu Dan Konsekuensi Ekonomis, Jurnal Akuntansi dan Keuangan Indonesia, 6, p: 20-45.10.

Francis, J. R. et. al. 2004. Costs of Equity and Earnings Attributes, The Accounting Review79: 9671010.

Ghozali, I. dan A. Chariri. 2006. Teori Akuntansi. Semarang: UNDIP.

Ghozali, Imam. 2009. Aplikasi Analisis Multivariat dengan Program SPSS. Semarang : Badan Penerbit UNDIP.

--------, Imam.2011.Aplikasi Analisis Multivariate Dengan Program IBM SPSS. Semarang : Badan Penerbit UNDIP.

Gunny, K. 2005. What are the Consequences of Real Earnings Management?. Working Paper. University of Colorado.

Halim, dkk. 2005. Pengaruh Manajemen Laba pada Tingkat Pengungkapan Laporan Keuangan pada Perusahaan Manufaktur yang Termasuk dalam Indeks LQ-45. Simposium Nasional Akuntansi VII. Bali.

Ifonie, Regina Reizky. 2012. Pengaruh Asimetri Informasi Dan Manajemen Laba Terhadap Cost Of Equity Capital Padaperusahaan Real Estate Yang Terdaftar Di Bursa Efek Indonesia. Jurnal Ilmiah Mahasiswa Akuntansi - Vol 1, No. 1.

Ikatan Akuntan Indonesia (IAI). 2009. Standar Akuntansi Keuangan, per 31 Oktober 2009. Jakarta: Salemba Empat.

Indriani, R., dan W. Khoiriyah. 2010. Pengaruh kualitas Pelaporan Keuangan Terhadap Asimetri Informasi. Simposium Nasional Akuntansi XIII, Purwokerto.

Kusuma. 2014. Pengaruh Kualitas Pelaporan Keuangan, Kepemilikan Institusional Dan Ukuran Perusahaan Terhadap Asimetri Informasi Pada Perusahaan Perbankan Yang Terdaftar Di BEI Tahun 2008-2012. Jurnal Akuntansi. Universitas Riau. Pekanbaru.

Kusumawati,dkk. 2013. Pengaruh Asimetri Informasi Dan Mekanisme Corporate Governance Terhadap Praktik Earnings Management. Proceeding Seminar National dan Call For Papers Sancall 2013. Surakarta.

Murtanto. 2004. Analisis Perataan Laba (Income Smoothing): Faktor-Faktor Yang Mempengaruhi Dan Kaitannya Dengan Kinerja Saham Perusahaan Publik Indonesia. Simposium Nasional Akuntansi VII. Bali. 
Pramesty, Tyas dan Restu Agusti. 2009. Pengaruh Asimetri Informasi, Ukuran Perusahaan, Kepemilikan Manajerial Terhadap Manajemen Laba. Jurnal Ekonomi Vol 17, No 01. Jurusan Akuntansi Fakultas Ekonomi Universitas Riau. Pekanbaru.

Putra, dkk. 2014. Pengaruh Asimetri Informasi Dan Ukuran Perusahaan Terhadap Praktek Manajemen Laba Pada Perusahaan Manufaktur Yang Terdaftar Di Bursa Efek Indonesia (BEI). e-journal Universitas Pendidikan Ganesha Jurusan Akuntansi S1. Volume: 2 No: 1 Tahun 2014.

Rahmawati, dkk. 2006. Pengaruh Asimetri Informasi Terhadap Praktik Manajemen Laba Pada Perusahaan Perbankan Publik Yang Terdaftar Di Bursa Efek Jakarta. Simposium Nasional Akuntansi IX. Padang.

Rahmawati. 2005. "Relevansi Nilai Informasi Akuntansi dengan Pendekatan Terintegrasi: Hubungan Nonlinier". Simposium Nasional Akuntansi VIII. Solo.

Riduwan dan Sunarto. 2014. Pengantar Statistika. Bandung: CV Alfabeta.

Sandra, Dessy dan Indra Wijaya Kusuma. 2004. Reaksi Pasar Terhadap Tindakan Perataan Laba dengan Kualitas Auditor dan Kepemilikan Manajerial sebagai Variabel Pemoderasi. Simposium Nasional Akuntansi VII. Bali.

Santoso. 2012. Pengaruh Kualitas Laporan Keuangan terhadap Asimetri Informasi dengan Ukuran Perusahaan sebagai Pemoderasi pada Perusahaan Manufaktur di BEI. Jurnal Ilmiah Mahasiswa Akuntansi Vol 1 No.4, Juli. Surabaya.

Sari, Sekar Mayang. 2004. Analisa Terhadap Relevansi Nilai (value-relevance), Laba, Arus Kas dan Nilai Buku Ekuitas: Analisa Diseputar Periode Krisis Keuangan 1995 - 1998. Simposium Nasional Akuntansi VII. Bali.

Scott, William R. 2000. Financial Accounting Theory. USA : Prentice-Hall

Setyaningrum dan Aprilia Yunita. 2011. Pengaruh Asimetri Informasi dan Ukuran Perusahaan Terhadap Manajemen Laba pada PerusahaanFood and Beverage yang Go Public di BEI. The Indonesia Accounting Review Vol 1 No.2, Juli 2011. Jawa Timur.

Subekti, Imam. 2005. Asosiasi Antara Praktik Perataan Laba Dan Reaksi Pasar Modal Di Indonesia. Simposium Nasional Akuntansi VIII. Solo.

Subhekti, Yogi. 2008. Faktor - Faktor Yang Mempengaruhi Praktik Perataan Laba (Income Smoothing) Dan Bukan Perataan Laba (Non Income Smoothing). Tesis. Universitas Sebelas Maret. Surakarta.

Sugiyono. 2006. Metode Penelitian Bisnis. Bandung : CV Alfabeta.

------. 2011. Metode Penelitian Kuantitatif dan Kualitatif dan R\&D. Bandung : CV Alfabeta.

Ujiyantho, Moh. Arief dan Bambang Agus P. 2007. Mekanisme Corporate Governance, Manajemen Laba dan Kinerja Keuangan. Simposium Nasional Akuntansi X. Makassar.

Veronica, Sylvia, dan Y.S. Bachtiar, 2004. Good Corporate Governance, Information Asymmetry, and Earnings Management. Simposium Nasional Akuntansi VII. Bali.

Watts, R. and J. Zimmerman. 1986. Positive Accounting Theory. Englewood Cliffs, New Jersey: Prentice-Hall.

www.idx.co.id 